\title{
Vitamin C content of freeze dried pequi (Caryocar brasiliense Camb.) pulp
}

\section{Soares, C.T. ${ }^{\text {a*}}$; Nogueira, G.F. ${ }^{\text {a }}$; Santana, A. A. ${ }^{\text {; }}$ Oliveira, R. A. ${ }^{\text {a }}$}

${ }^{a}$ School of Agricultural Engineering, University of Campinas, Campinas - SP, Brazil.

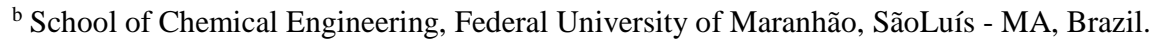

*E-mail of the corresponding author: augustus@ feagri.unicamp.br

\begin{abstract}
Vitamin C is one of the constituents of pequi pulp. It is a natural antioxidant, capable of sequestering free radicals. The present study aimed to freeze dry a pequi pulp encapsulated with maltodextrin and whey protein and analyze vitamin C content. Vitamin C loss was lower in the experimental run that did not use encapsulating agent. Whereas, the run that used $15 \%$ of whey protein concentrate as encapsulant agent in relation to pequi solids presented the highest value (220.74 mg vitamin C / g pequi solids). Freeze drying of pequi pulp is a technique for vitamin C conservation independently of the variation in maltodextrin and whey protein proportion.
\end{abstract}

Keywords: drying; encapsulating agent; ascorbic acid. 


\section{Introduction}

The pulp of pequi (Caryocar brasiliense Camb.) is rich in vitamin $\mathrm{C}$, which present antioxidant capacity [n1]. This fruit is produced in the regions that compose the Brazilian Cerrado biome and because of this, it is an extractive product. The lack of adequate methods of conservation and perishability of the fruit result in great loss [n1]. New technologies allow the aggregation of value to the product and among them is freeze drying. This technique minimizes losses of nutrient compounds during the drying process based on the dehydration by sublimation of a frozen product resulting in a dry material [n2, n3]. Microencapsulation is a technique that maintains product properties as stable as possible and extends its shelf-life. Encapsulating agents protect the core material from interaction with environmental factors such as light, oxygen, temperature and humidity, and among them are maltodextrin and whey protein concentrate (WPC). Maltodextrin is a partially hydrolyzed starch widely used in the food industry as it has a mild and long-lasting flavor [n4]. WPC is an excellent protein isolate in the edible coating, as well as in food enrichment and edible film production [n5]. The objective of this work was to dry the pequi pulp encapsulated with maltodextrin and WPC and to analyze the composition of vitamin C after freeze drying process.

\section{Materials and Methods}

\subsection{Materials}

Pequi fruits from a single batch production of the state of Minas Gerais, Brazil, were purchased at the Campinas Supply Center (Ceasa-Campinas) and used on all the experiments. After processing, the samples were stored in a freezer at $-60 \pm 3{ }^{\circ} \mathrm{C}$ and dried by a laboratory freeze dryer (Edwards High Vacuum, Super Modulyo model, Great Britain). Maltodextrin (MOR-REX® 1910, Ingredion, Mogi-Guaçu, Brazil) and whey protein concentrate (WPC 80, Alibra, Campinas, Brazil) were used as encapsulating agents.

\subsection{Methods}

\subsubsection{Preparation of pequi pulp}

The fruits were stored in a Biochemical Oxygen Demand (B.O.D.) chamber at $5{ }^{\circ} \mathrm{C}$ until their processing stage. The pequi pulp processing followed the subsequent steps: selection, washing, sanitization, peeling, second sanitization, pulping, packaging, homogenization. Homogenization was carried out by a domestic mixer, adding distilled water in the 
proportion 1: 1 (pulp:water, $\mathrm{m} / \mathrm{m}$ ) to the pequi pulp and different encapsulants in different concentrations, according to Table 1.

A central composite experimental design with two independent variables and three central points, totalling 11 experimental runs, was performed. The independent variables were the maltodextrin/whey protein concentrate proportion and total concentration of encapsulating in relation to total solids content of pequi pulp.

Vitamin C content after freeze drying were considered the dependent variable (response). Table 1 presents the encoded and real values of independent variables of the experimental design. In Table 1, $\mathrm{C}_{\text {total }}$ : total concentration of encapsulants in relation to the total solids of pequi pulp. $\mathrm{C}_{\mathrm{WPS}}$ : whey protein concentrate concentration. $\mathrm{C}_{\mathrm{M}}$ : maltodextrin concentration.

Table 1. Experimental design

\begin{tabular}{cccccc}
\hline \multirow{2}{*}{ Run } & \multicolumn{5}{c}{ Independent variables } \\
\cline { 2 - 6 } & CM \% & Ctotal [\%] & CM \% & CW \% & Ctotal [\%] \\
\cline { 2 - 6 } & -1 & -1 & 14,6 & 86,4 & 4,4 \\
2 & -1 & 1 & 14,6 & 86,4 & 25,6 \\
3 & 1 & -1 & 85,4 & 14,6 & 4,4 \\
4 & 1 & 1 & 85,4 & 14,6 & 25,6 \\
5 & $-1,41$ & 0 & 0,0 & 100,0 & 15,0 \\
6 & 1,41 & 0 & 100,0 & 0,0 & 15,0 \\
7 & 0 & $-1,41$ & 50,0 & 50,0 & 0,0 \\
8 & 0 & 1,41 & 50,0 & 50,0 & 30,0 \\
9 & 0 & 0 & 50,0 & 50,0 & 15,0 \\
10 & 0 & 0 & 50,0 & 50,0 & 15,0 \\
11 & 0 & 0 & 50,0 & 50,0 & 15,0 \\
\hline
\end{tabular}

Variation of the parameters encapsulant concentration, maltodextrin / WPC $\left(C_{\text {enc }} \%\right)$ and relation between the encapsulant and ST of the pulp (Total ratio $_{\text {\%). }}$

\subsubsection{Freeze drying}

The samples were previously prepared with the addition of the encapsulants according to the planning design, forming distinct treatments and, later, placed in stainless steel trays of the freeze-dryer with capacity of $200 \mathrm{~g}$ each one and submitted to freezing in a freezer at - 
$60^{\circ} \mathrm{C}$ before starting the freeze-drying process. After freezing, the samples were taken to the freeze dryer, which consists of a vacuum chamber, condenser, refrigeration unit, and vacuum pump. The average time for freeze drying of the samples was about 72 hours. Then, the porous plates obtained in this process were broken using a porcelain mortar and pestle and, after that, homogenized.

\subsubsection{Vitamin $C$}

For the analysis of vitamin $\mathrm{C}$, absorbance readings were performed in a spectrophotometer at $760 \mathrm{~nm}$ using trichloroacetic acid and Folin-Ciocalteu Phenol 2.0N as reagents, described by Jagota and Dani [n6]. Vitamin C was quantified based on a standard curve fitted from various dilutions of vitamin $\mathrm{C}$ ( 5 to $70 \mu \mathrm{g}$ ). The values were expressed as mg of vitamin $\mathrm{C}$ in $100 \mathrm{~g}$ of pequi pulp.

\subsubsection{Statistical analysis}

Significant differences between average results were evaluated by analysis of variance (ANOVA) and Tukey test at 5\% of level of significance, using SAS software (Cary, NC, USA).

\section{Results and discussion}

The vitamin $\mathrm{C}$ results of the pequi pulp encapsulated with maltodextrin and whey protein are shown in Table 2. Vitamin $\mathrm{C}$ for fresh pequi pulp was $311.72 \pm 1.25 \mathrm{mg}$ of ascorbic acid $\mathrm{g}^{-1}$ solids of pequi. The vitamin $\mathrm{C}$ values of the experimental runs ranged from 99.03 to $220.74 \mathrm{mg}$ of ascorbic acid $\mathrm{g}^{-1}$ solids of pequi being within the values found by [n7] for spray dried pequi pulp. Run 7, with no encapsulating agent, presented lower vitamin $\mathrm{C}$ content compared to the other runs. It is believed that the use of encapsulating agent had a significant effect on the conservation of vitamin $C$, especially when the percentage of whey protein in the total solids of the pulp was used (run 5). The pequi pulp encapsulated with maltodextrin and whey protein concentrate, after freeze drying process, suffered losses of vitamin $\mathrm{C}$ when compared to the fresh pulp. However, when compared to the nonencapsulating agent run, the losses were not pronounced, showing that the technique of encapsulation has protected the oxidation of ascorbic acid from a number of biochemical mechanisms, which are responsible for the loss of vitamin $\mathrm{C}$ activity.

Even the lowest content of vitamin $\mathrm{C}$ found in experimental runs is superior to that of raw avocado fruit, 'Maçã' banana, 'Nanica' banana, cupuassu, jackfruit, 'Red Delicious' apple, 
'Fuji' apple, watermelon, 'Williams' pear, 'Aurora' peach, pomegranate, tamarind, umbu and 'Ruby' grape [n8].

Table 2. Vitamin C for freeze dried pequi pulp using maltodextrin and WPC as encapsulant agent.

\begin{tabular}{ccccc}
\hline Run & $\mathbf{C}_{\mathbf{M}}(\boldsymbol{\%})$ & CWPS $(\%)$ & $\mathbf{C}_{\text {total }}(\boldsymbol{\%})$ & $\begin{array}{c}\text { Vitamin C (mg / g solids } \\
\text { of pequi) }\end{array}$ \\
\hline 1 & 14.6 & 85.4 & 4.4 & $183.48 \pm 2.77 \mathrm{~g}$ \\
2 & 14.6 & 85.4 & 25.6 & $191.06 \pm 0.98 \mathrm{ef}$ \\
3 & 85.4 & 14.6 & 4.4 & $186.59 \pm 1.07 \mathrm{gf}$ \\
4 & 85.4 & 14.6 & 25.6 & $213.14 \pm 2.25 \mathrm{bc}$ \\
5 & 0.0 & 100.0 & 15.0 & $220.74 \pm 2.54 \mathrm{a}$ \\
6 & 100.0 & 0.0 & 15.0 & $196.62 \pm 0.41 \mathrm{ed}$ \\
7 & 50.0 & 50.0 & 0.0 & $99.03 \pm 2.73 \mathrm{~h}$ \\
8 & 50.0 & 50.0 & 30.0 & $202.33 \pm 1.47 \mathrm{~d}$ \\
9 & 50.0 & 50.0 & 15.0 & $210.76 \pm 3.14 \mathrm{c}$ \\
10 & 50.0 & 50.0 & 15.0 & $196.06 \pm 2.16 \mathrm{ed}$ \\
11 & 50.0 & 50.0 & 15.0 & $219.41 \pm 2.14 \mathrm{ba}$ \\
\hline
\end{tabular}

*Same letters in the column show no statistical difference $(\mathrm{p}>0.05)$.

Experimental data of vitamin $\mathrm{C}$ for freeze dried pequi pulp using maltodextrin and WPC as encapsulant agent are shown in Table 2. The experimental values of vitamin $\mathrm{C}$ oscillated from 99.03 to $220.74 \mathrm{mg}$ vitamin $\mathrm{C} / \mathrm{g}$ solids of pequi.

The determination coefficient $\left(\mathrm{R}^{2}\right)$ for the fitted model was 0.75 . The model was tested for adequacy and fitness by the analysis of variance (ANOVA) without considering the nonsignificant terms $(\mathrm{p}>0.05)$. The coded second-order polynomial model (Equation 1) was considered significant and predictive.

Vit. $C\left[\frac{m g}{g_{\text {solids of pequi }}}\right]=211.98+22.53 C_{\text {total }}-26.57 C_{\text {total }}^{2}$

Fig. 1 shows the contour plot generated by the proposed model. It is observed that there is no influence of maltodextrin/WPC proportion on Vitamin C values. 


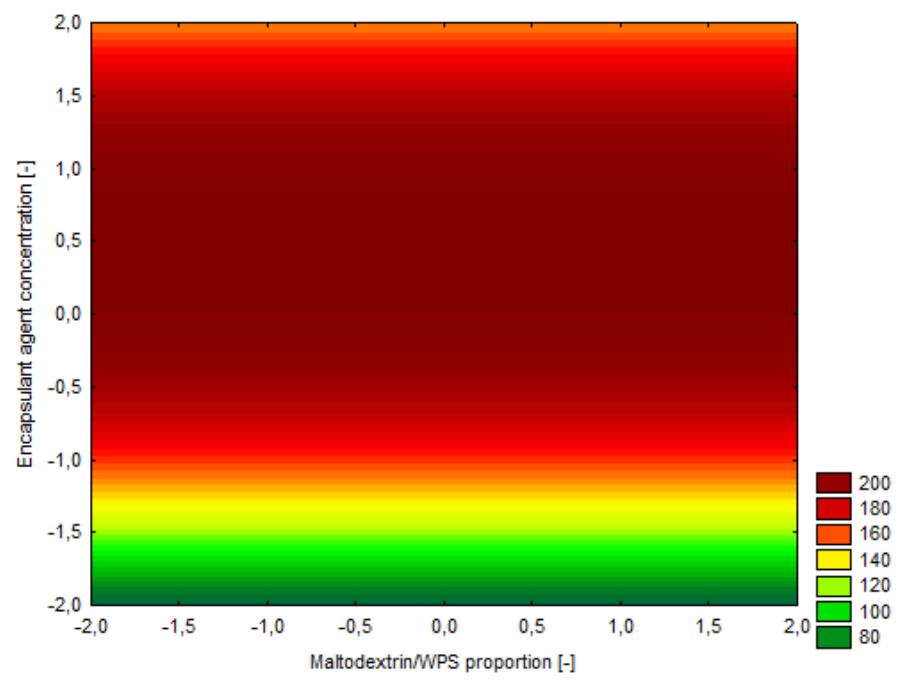

Fig. 1 Response surface for vitamin C content of microencapsulated pequi powder.

\section{Conclusions}

The experimental run using no encapsulant agent on freeze drying process has a lower vitamin $\mathrm{C}$ value because of the absence of protection against ascorbic acid oxidation. The runs that showed the best protection against oxidation of ascorbic acid were those encapsulated with $15 \%$ independent of the encapsulant used. Drying of pequi pulp by freeze drying is an excellent technique for the protection of ascorbic acid, regardless of variation (proportion) in the use of maltodextrin and/or whey protein concentrate (WPC).

\section{References}

[1] Carrazza, L.; Ávila, J. C. C. Manual Tecnológico de Aproveitamento Integral do Fruto do Pequi. Brasília - DF. Instituto Sociedade, População e Natureza (ISPN). Brasil, 2010, p. 7-11.

[2] Ordóñez, J. A. Tecnologia de alimentos: Componentes dos alimentos e processos. Porto Alegre: Artmed, v.1, 2005, p. 220-225.

[3] Fellows, P. J. Tecnologia do Processamento de Alimentos: Princípios e prática. Tradução: Florencia Cladera Oliveira, Jane Maria Rubensan, Julio Alberto Nitzkee Roberta Cruz Silveira Thys - $2^{\circ}$ edição - Porto Alegre: Artmed, 2006.

[4] Gibbs, B.F.; Kermasha, S.; Alli, I.; Mulligan, C.N. Encapsulation in food industry: A review. International Journal of Food Science and Food Nutrition, v.50, 1999, p. 213234. 
[5] Yoshida, C. M. P. \& Antunes, A. J. Aplicação de filmes proteicos à base de soro de leite. Ciência e Tecnologia de Alimentos, Campinas, v. 29, n. 2, 2009, p. 420-430.

[6] Jagota, S. K. \& Dani, H. M. A new colorimetric technique for the estimation of vitamin $\mathrm{C}$ using folin phenol reagent. Analytical biochemistry. Panjab University, India, 1982.

[7] Santana, A.; Kurozawa, L.; Oliveira, R.; Park, K.. Spray Drying of Pequi Pulp: Process Performance and Physicochemical and Nutritional Properties of the Powdered Pulp. Brazilian Archives of Biology and Technology, v. 59, 2016, p.1-11.

[8] Nepa - Núcleo de Estudos e Pesquisas em Alimentação (Unicamp). Tabela Brasileira de Composição de Alimentos. 2 ed. Campinas: NEPA-UNICAMP, 2006, 102-104. 